\title{
Paul Yakovlev Remembered: An Interview with Maurice Victor
}

\author{
Robert Laureno
}

\begin{abstract}
Maurice Victor, the great Canadian neurologist, was an expert on the neurology of alcoholism including the Wernicke-Korsakoff syndrome. In Boston, Massachusetts he encountered the leading neuroanatomist, Paul Yakovlev, an immigrant from Russia. Together Victor and Yakovlev collaborated on translating the work of S.S. Korsakoff from Russian to English. This interview of Victor about Yakovlev is informative about both of these great figures in North American Neurology.
\end{abstract}

RÉSUMÉ: Une entrevue avec Maurice Victor en souvenir de Paul Yakovlev. Maurice Victor, un grand neurologue canadien, était un expert en neurologie de l'alcoolisme et du syndrome de Wernicke-Korsakoff. Il a rencontré à Boston au Massachusetts l'important neuroanatomiste Paul Yakovlev, un immigrant originaire de Russie. Victor et Yakovlev ont collaboré à la traduction du russe à l'anglais de l'œuvre de S.S. Korsakoff. Cette entrevue avec Victor concernant Yakovlev nous éclaire sur ces grandes figures de la neurologie nord-américaine.

Can. J. Neurol. Sci. 2009; 36: 311-314

Maurice Victor $^{1}$ of Winnipeg went for his residency to Boston, USA, where he encountered Paul Yakovlev, ${ }^{2}$ a Russian emigree. It was my privilege to interview Victor in October 2000 when we were at the meeting of the American Neurological Association in Boston. There follows a transcription of his comments on Yakovlev. This interview contributes to the historical record of these men, both important figures in North American neurology. It provides information on Yakovlev's personality, interests and work habits, and it demonstrates Maurice Victor's power of description, which contributed to his masterful teaching and writing.

Before Victor arrived in Boston, Yakovlev was well known as an anatomist and investigator. His neuroanatomy teaching sessions at Fernald School would continue well after midnight, as long as the residents and students would stay. Yakovlev's publications on normal adult neuroanatomy, ${ }^{3}$ normal developmental anatomy ${ }^{4}$ and developmental diseases ${ }^{5,6}$ were important contributions to these fields of study.

At Boston City Hospital, Maurice Victor found his mentor in Raymond Adams. Together, Victor and Adams delineated the major categories of neurological disorder seen in alcoholic patients. Their stunningly good work included classification of the withdrawal syndromes, ${ }^{7}$ the first description of central pontine myelinolysis, ${ }^{8}$ the classic monograph on nutritional cerebellar degeneration ${ }^{9}$ and the definitive volume on WernickeKorsakoff Syndrome. ${ }^{10}$

Through his interest in the latter disease, Victor became an expert on memory and its anatomical basis. However, he could not read the original works on Korsakoff's psychosis; they had never been translated from Russian into English. Victor obtained microfilm of Korsakoff's writings, and Paul Yakovlev was willing to translate them. Their hours of collaboration on this project $^{11}$ are the basis of many of Victor's recollections about Yakovlev.

\section{INTERVIEW}

RL - Please tell me about Paul Yakovlev.

MV - Paul Yakovlev was a remarkably interesting man, a Russian, of course. Paul Yakovlev was a graduate of a leading Russian medical school. He graduated at the time of the tremendous ferment in Russia, in 1917, during the Russian revolution. The entire country was in chaos. Paul Yakovlev decided that he had to get out of Russia to salvage a semblance of personal life and professional life, and he had the most harrowing experiences in doing that. He literally walked from Leningrad to the capital of Finland, across the ice.

And then, from there, he made his way to Paris, where for five years he was the chief assistant to Joseph Babinski. That was the beginning of his interest in neurology and neuropathology. But Paul Yakovlev soon found that his interest lay in developmental neurology ... in how the nervous system developed, how parts of it connected to one another, and what it

From the Department of Neurology, Washington Hospital Center and Department of Neurology, Georgetown University, Washington, DC, USA.

Received October 7, 2008. Final Revisions Submitted December 10, 2008 Correspondence to: Robert Laureno, Department of Neurology, Washington Hospital Center, 110 Irving St., NW, Washington, DC, 20010, USA. 


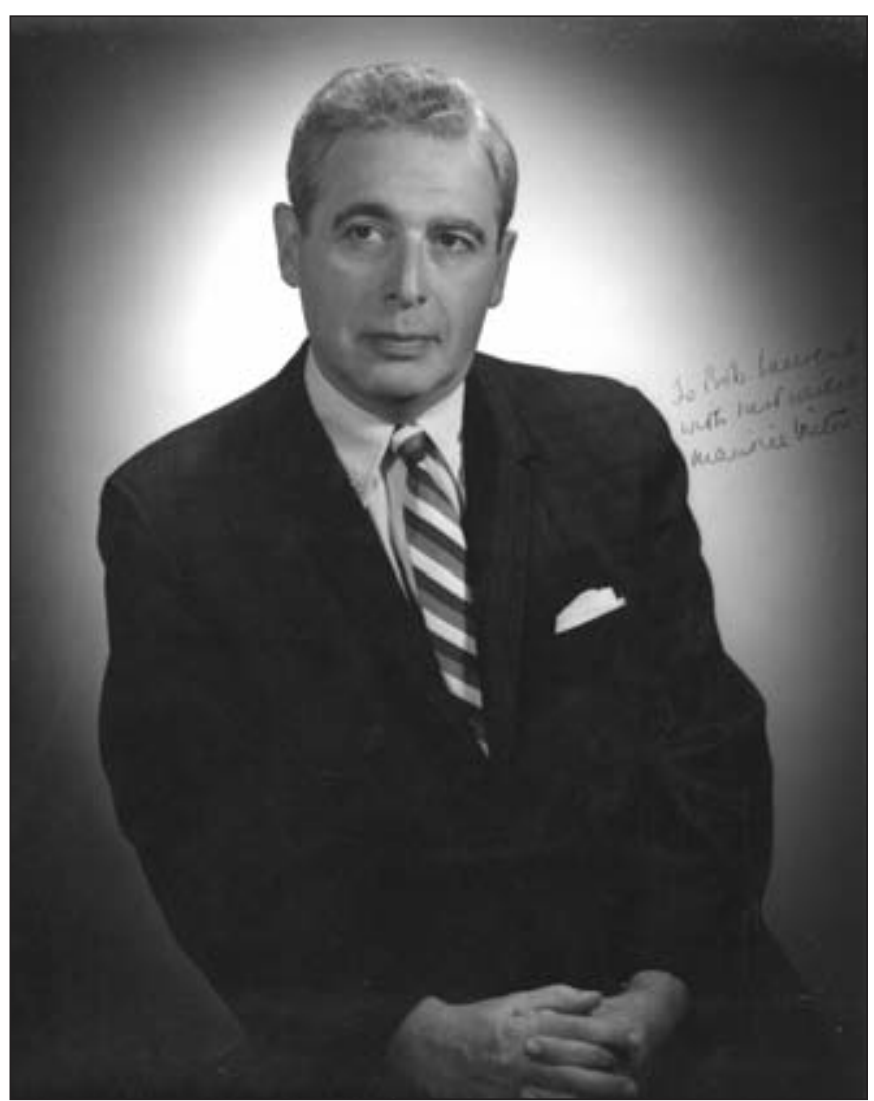

Figure 1: Maurice Victor: 1920-2001

all meant in a clinical, philosophical sense. And then he left Paris. I imagine it was very difficult making headway in the rigid, academic atmosphere that existed in France. I mean Babinski couldn't make headway in it. Babinski was at the periphery of French neurology, despite his tremendous accomplishments and his obvious brilliance, and, certainly, I presume there'd be no room or opportunity for his assistant.

He came to America, friendless, not really known in the neurological field at all. And he went to work as neurologist neuropathologist in various mental institutions in New England. Mainly he worked in Connecticut, at homes for the mentally retarded, and then, he began to put together various types of developmental defect ... that resulted in life long epilepsy and mental retardation.

Gradually, it became known that, hidden away in these homes for the mentally retarded, was this remarkably brilliant person. Very pleasant, very friendly, he loved to talk about his observations, and, gradually, people began to recognize that and to congregate there. Among those people was Ray Adams. If he would make a trip in that direction ... he always made sure to stop in and talk to Paul Yakovlev, asking questions that had come up in the course of some of their cases, and always what they received from the man were the most interesting and imaginative concepts of disease. He had this wonderful capacity to look down on the brain, like an astronaut in space might look down at the Earth; he would encompass the entire brain in terms of its workings and connections. And he invented a method of doing entire brain slices on a big sledge that he devised. He then stained them with myelin and cell stains and showed how certain areas in the cerebral cortex connected with other areas of the cerebral cortex and particularly with nuclear masses below the cortex, and he redid the concepts that existed about intracerebralcortical connections. He was a person just bubbling over with ideas on how the brain worked. Eventually, through the graces of Ray Adams, he got himself some space at the Harvard Medical School, and there he worked away and developed his ideas, attracted fellows, who came to work with him, some of them now very famous men.

He had this concept of a three-layered nervous system. One, a core of neural elements that had to do with enteroception; the most visceral feelings and emotions traveled in this core. And then the exteroceptive system, in which he listed the anterior horn cells and the major motor areas of the cortex, which dealt with the world without. And then a group of neurons and fibers, which connected the two systems. And it's very interesting that, if you read modern writers of so-called, higher cortical functions, particularly Mesulam, who, I think more than anybody that's alive now, has thought seriously about these things, he has, in a sense, adopted the Yakovlev way of thinking about the nervous system. ${ }^{12}$

So he was a man of great intellectual capacity who could find a challenge in each and every abnormality that he saw in the brain, and he described certain abnormalities of the developing brain better than anybody ... the lissencephalies and the schizencephalies, and so on. He described a lot of clinical syndromes, based on what he saw in the mental hospitals, that were new concepts, for example, paraplegia of cerebral origin. (Paraplegia had always been thought to be of spinal cord origin.) A very original fellow, interested in each and every concept of what made people become crippled, what caused them to curl up. In our textbook we've reproduce his drawings on the effect of aging on the nervous system. ${ }^{12}$

Although Russian, he had a remarkable feeling for the English language. He used to give long dissertations on the distinctions between words for example, "myoclonus" and "myoclonic." He would, for instance, give me long dissertations on why Korsakoff's pyschosis had to be spelled with two "f's" at the end instead of a "w" or a "v," things such as that. He was interested in all kinds of intellectual activity.

RL - You collaborated with him on a translation.

MV - Yes, we translated all of Korsakoffs' writings. We used to do them out in his little camp. He had a dilapidated little camp out in Harvard, Massachusetts. And well into the fall, when it was miserably cold, he used to insist on going out to his cabin, and we used to translate them from microfilm that was available in the Library of Congress. We managed to get the microfilms of Korsakoff's writings, and we could look at them under a dissecting microscope. And his job was to translate it from Russian, and I would scribble it down in English. And we systematically worked our way; it took a long time because we had to do this after a day's work at the Warren museum. And I still have them. We wrote a paper with excerpts from Korsakoff's third article (the best developed article on his psychosis) with commentary. ${ }^{11}$ Many people have asked for reprints of it because 


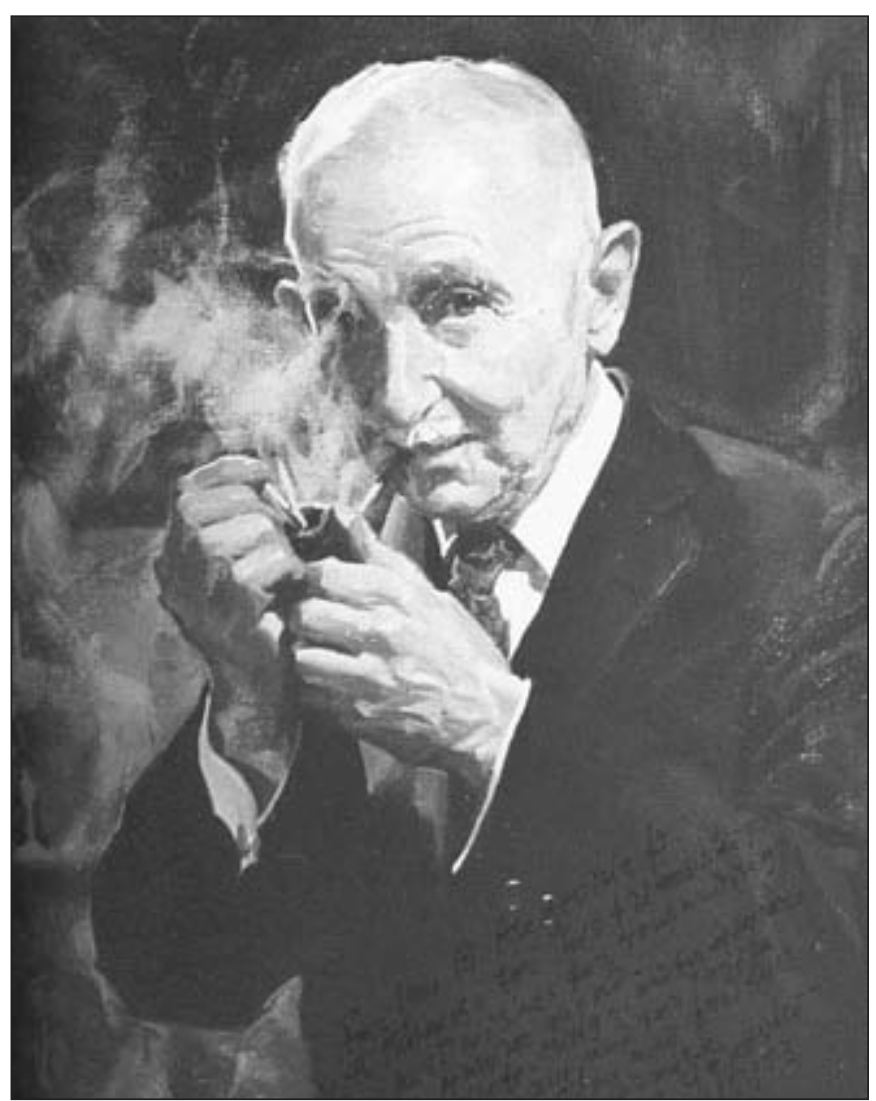

Figure 2: Paul Yakovlev: 1894-1983

it's very hard to come by Korsakoffs' writings. He was truly an expert because Russian was his native tongue, and he enjoyed doing it very much.

RL - At what time of day did you do this work?

MV - We did it all in the evening. And it would go on and on because he was a night owl. He'd get up late in the morning but he would work till 3 or 4 o'clock in the morning. It was very hard on me because I was the opposite. By 3 or 4 the next morning I'd be dead, and he'd still be going strong, wanted to do more.

I'd go over to his house and he had this characteristic Russian way of talking, you know... no adjectives, no adverbs, and no conjunctives, no articles. He would say: "Make sandwich." And he would take two pieces of rather stale Wonder Bread and put a piece of bologna in between (clap); that would constitute a sandwich. That would be our supper, by the way. He would wrap it in a newspaper, and we would take it along with us to this camp at Harvard. And he drove like a mad man; he didn't watch the road. If he had to explain how certain pathways develop in the brain, he'd take his hands off the wheel, and gesture with his hands (It was reminiscent of a movie, called "Scent of a Woman," in which a blind man drives a Ferrari through the streets of New York.), until I decided I couldn't stand it.

So I would have a bite to eat before I went to his house, and then I insisted on driving out in my car, so at least I was saved the stress of that. Then we would sit and translate and, there would be numerous interruptions, in which he would have to explain to me the fine nuance of what Korsakoff was saying. If the patient beat his breast and uttered certain things, all recorded in Korsakoff's history, he would take a long interlude to explain to me how only Russian patients beat their breasts ... all very interesting.

And then he objected to some of my remarks about phraseology. If he would say, "the matter of the fact is" (he was translating), and I had the temerity to say," well, I think the conventional way of saying that is, 'the fact of the matter' ", he'd say, "no, no, no it's "the matter of the fact". So I would write down, "the fact of the matter". He'd jump up from his microscope and look, and he would insist that I change it. (Laugh) And so it went ... it was a delightful experience with that man, and then, every now and then, when we would finish with one of the papers, he would decide that he wanted it in a different tense, that he just couldn't use the tense in Russian, that it would have to be changed to some other tense. So we'd go over the whole paper and change all of the verbs. And then he decided that no, the original way was better, and so we went back and forth. And I remember, we finally got to the last article. And we drove back and I had to drop him off at his house in Brookline. I dropped him off, walked into the house with him, and he relaxed in the chair. This was about 3 o'clock in the morning by this time, and he said "Now Wictor," ("v's" were pronounced "w"), "Wictor" he said, "read this back to me" (that was the final article) "with feeling".

So I struggled, and I read it back to him, and, intermittently, he was so impressed with the translation (which was his) that he would jump up and he would say, "What a translation!" And then he said to me, I remember those words, he said, when I finished reading it to him with feeling, "What a wonderful translation". And he said, quite objectively, as if he had no part of it,"this is not Yakovlev speaking, this is not Wictor speaking, this is Sergei Sergeievich speaking." We had come to refer to Korsakoff by his patronymic because of our familiarity. And then he gave me a long talk about the Russian habit of using the patronymic, that it is not a sign of disrespect. It is a sign of deep, abiding friendship and understanding of the person. So I followed suite; we kept referring to Korsakoff as Sergei Sergeievich. And then he uttered the ultimate compliment. He said, "You know Wictor, if Sergei Sergeievich had gone to Harvard Medical School, this is the way he would have written the article!" (laugh) So by this time I was dead tired. It was about 4:30 am and I staggered up, ready to go home. He said "Leaving?" I said, "Yeah ... gotta get up early". He said, " Too bad, would have liked for you to stay and have a chat."

RL - Was he Jewish?

MV - No, no. He was an eminent example of the Russian intellectual of the pre-revolutionary period. Courtly, gentlemanly, interested only in the high matters of the mind. And, of course, innately very, very brilliant.

RL - To what extent were his concepts about sequential myelination of the human brain original?

MV - They were not original. They were refinements of the method that had been well developed long before his time. ${ }^{12}$

RL - Did he originate the diagrams which illustrated the sequential myelination?

MV - When he refined the ages of myelination, those became the standard, I think, for teaching about the subject. 
RL - Did he tell you anything about the way that Babinski would elicit his sign?

MV - Oh yes! He had many stories about Babinski, whom he admired: of Babinski making entire rounds, doing nothing but testing for the sign; of a nurse, following them around with a pan of warm water, in which to place the patient's feet for a certain length of time before they tested for the sign, so it would be easier to elicit; of Babinski insisting on using a noxious stimulus to elicit the sign, like a sharp needle, but insisting that nobody else use the needle because they were untrustworthy. They'd have to know how to use the needle.

One of the first things Paul did when he got in-charge of all these homes for the mentally retarded, was to test out some of Babinski's notions that if you warm the feet, for example, you can elicit the sign easier than in cold feet. And so, he would take a gang of about 20 retarded patients on a hike, a long hike, miles and miles. And after, let us say, five miles of walking, he would get them to sit down in a ditch, take off their shoes and stockings, and test all of them for the Babinski sign. And then he would get them to put on their shoes and stockings, walk another five miles, and then retest and see how much more frequently he could elicit the sign, and so on. He had all these fanciful little things that he did, that he recorded in his head. He never wrote it down; he would tell us about it. And I could just picture him in a big straw hat and a stick walking ahead of this gang, enjoying himself.

RL - I met him after he had moved his slide collection to the Armed Forces Institute of Pathology. He recommended using the end of a paper clip to test for the Babinski sign.

MV - That I didn't know. But that was the sad part of his life. Those were the very latter years of his life, when he was in his 80 's. And it came about in a rather sad way. It was an argument at the Warren museum over space. The person, running the Warren museum at that time, insisted on demoting Paul, kicking him out of the Warren museum. And Ray Adams took him over to either the Fernald School or the Shriver, I don't know which, and ensconced him in the basement there with his collection. And then they needed more space in Fernald and so they squeezed him a little bit more, but he couldn't stand it, and he picked up his collection, made many trips with the big trays and slides over to the Armed Forces, where they welcomed him and put up his collection. His last years ended in a rather rancorous way.

\section{DISCUSSION}

Having been a neurology resident with Maurice Victor, I knew well his eloquence, humor and skill at observation. I was certain that he would be an excellent source of information about the history of North American neurology. For years, I had encouraged him to allow me to interview him for the historical record. He finally agreed. His intention was to describe the most important neurological figures, whom he had come to know during his years in Boston. During one interview he described Derek Denny-Brown, Raymond Adams ${ }^{13}$ and Paul Yakovlev. We were to meet again for him to describe C. Miller Fisher and E.P. Richardson, but Victor's prostate cancer interfered. The second interview never occurred.

Maurice Victor's account of Paul Yakovlev documents Victor's story telling ability, which was integral to his teaching style. At his Saturday conferences at Cleveland Metropolitan General Hospital he would intertwine his exposition of a patient with anecdotes about other patients he had seen, tales about interesting neurologists he had known, and observations about human behavior that he had made in non-medical settings. These stories, often humorous, were all somehow relevant to the neurological case under discussion. One could never lose interest.

Both of these colorful neurologists, Yakovlev and Victor, made important original contributions to the profession. The legacy of each, however, goes beyond their landmark articles. Principles of Neurology ${ }^{12}$, which Victor authored with Raymond Adams, thrives. It has been described as a "gem", as the best piece of medical writing since Cushing. Although both authors have died, the text book continues as Adams and Victor's Principles of Neurology. It will soon appear in its ninth edition. Yakovlev's collection of 820 human and 123 animal brains is now at the National Museum of Health and Medicine in the Armed Forces Institute of Pathology, Washington, D.C., Yakovlev preserved these specimens in stained serial sections of whole brain. The Yakovlev collection ${ }^{14}$ continues to be a resource for teaching ${ }^{15}$ and investigation.

\section{ACKNOWLEDGEMENTS}

The author thanks Dr. Thomas Kemper and Dr. Jay Angevine for their assistance in obtaining portraits. Also a thank you to Mrs. Louella Baterna for preparation of the manuscript.

\section{REFERENCES}

1. Johnson RT: Maurice Victor. 1920 - 2001. Ann Neurol. 2001;50: 831.

2. Kemper T. Paul Ivan Yakovlev. Arch Neurol. 1984;41:536-40.

3. Singer M, Yakovlev P. The human brain in sagittal section. Springfield (Il): Charles C. Thomas. 1954.

4. Yakovlev PI, Lecours AR. The myelogenetic cycles of regional maturation of the brain. In: Minkowski A, editor. Regional development of the brain in early life. Oxford: Blackwell; 1967. p. 3-70.

5. Yakovlev PI, Wadsworth RC. Schizencephalies: a study of the congenital clefts in the cerebral mantle. Neuropathol Ext Neurol. 1946;5(116):169.

6. Yakovlev PI, Guthrie RH. Congenital ectodermoses (neurocutaneous syndromes) in epileptic patients. Arch Neurol Psychiatry. 1931;26:1145.

7. Victor M, Adams RD. The effect of alcohol on the nervous system. Res Publ Assoc Res Nerv Ment Dis. 1953;32:526.

8. Adams RD, Victor M, Mancall EL. Central pontine myelinolysis. Arch Neurol Psychiatry. 1959;81:154.

9. Victor M, Adams RD, Mancall EL. A restricted form of cerebellar degeneration occurring in alcoholic patients. Arch Neurol. 1959; 1:577.

10. Victor M, Adams RD, Collins GH. The Wernicke-Korsakoff syndrome and related neurologic disorders due to alcoholism and malnutrition. 2nd ed. Philadelphia: Davis;1989.

11. Victor M, Yakovlev PSS. Korsakoff's psychic disorder in conjunction with peripheral neuritis. A translation of Korsakoff's original article with brief comments on the author and his contribution to clinical medicine. Neurology. 1955;5: 394-406.

12. Adams R, Victor M. Principles of Neurology. 1st ed. New York: McGraw Hill; 1977.

13. Laureno R, Raymond Adams. A life of mind and muscle. Oxford University Press. In press 2009.

14. The Yakovlev Collection. J Neuropathol Exp Neurol. 1983;42 (6):725.

15. Nolte J, Angevine JB. The human brain in photographs and diagrams, 2nd ed. St. Louis: Mosby; 2000. p. 212. 